\title{
Conflict Peace and Security: The Nigeria Experience
}

\author{
Yisa Jonah $^{1} \quad$ Yemisi Olawale ${ }^{2}$ \\ 1.Department of History, Niger State College of Education, Niger State \\ 2.History and International Studies, Osun State University, Oshogbo
}

\begin{abstract}
Conflict, peace and security issues today have become a matter of global concern. Every society on earth is riddled with conflict but there is no societies that will want conflict to degenerate into crisis talk less of violence or war. In Nigeria today, crisis of boko haram insurgency, Fulani herdsmen and farmers clashes, cattle rustling, militant group crisis, political crisis, corruption and a host of others have caused a lot of challenges that has threaten the cooperate existence of the country. Many have attributed this to environmental conditions which are mainly man made. What is the experience of Nigeria as a nation and how has the situation been managed? This paper, therefore reviews conflict, peace and security in Nigeria by examining the environmental conditions responsible, management of security issues, national security frame work put in place to address the issues and its effect.
\end{abstract}

Keywords: Conflict, Peace, Security and Development

DOI: $10.7176 /$ RHSS/9-1-07

\section{Introduction}

Scholars, Researchers, policy makers in Nigeria have become interested in matters of conflict, peace, and security in Nigeria. The reasons for this paradigm shift are their quest for national integration, nation building, development, and peaceful cooperation among various ethnic groupings in the country. Nigeria is a plural society, such a society, expectedly could be bedeviled with social conflict, as it is natural for people to hold fast to their prejudices and desires which explain why conflicts occur in most part of the country (Okpevra 2005). Conflict is an inevitable phenomenon in this universe. As long as human exists, there must be conflictual interest which is a substantial reason for human existence. Just as conflict is inevitable, it management and eventual conflicts resolution is imperative for the purpose of peace and security of lives and properties. If conflictual situations are not properly managed through conflict management, resolution and peace building, it degenerates into crisis and eventually violence situation which could be devastating and prevent development.

Taking into consideration the inevitability of conflict, the whole world is in the danger of this all. On a global plane, every continent in the world, countries in different continent, communities in state, family in communities has its share in conflict. Certainly, social groupings crave for peace and security recognizing the importance to their livelihood and existence. In Africa, conflict has resulted into the death of millions, generated millions of refuges and internally displaced persons, uncountable number of physically wounded and people are psychologically traumatized., Africa (Nigeria) through the conflict, wars, riots of independence and liberation movement to civil wars, proxy wars during the cold war, military intervention in politics, inter-communal conflict, ethnic violence, religious conflict, environmental/resources conflict have all degenerated into violence. Unequivocally, most of this conflict have not been properly managed and resolves thereby leaving back bitter memories which still lead to disagreement such as the case Nigeria a Civil War, Rwanda Civil War, Somalia, Liberia, Libya, Central African Republic and Sudan are all experiencing one form of conflict or the other at present.

The Nigeria history can be adequately grounded through a complacent study of the state experience in the sphere of conflict, peace, and security overtime. According to Best (2004), posited that hardly was any region spared from some of these conflicts, even though the conflict differs in prevalence and intensity, or their protracted or un-protracted nature. In the far North for instance, conflict of religious nature continued to break out at location like Kano, Kaduna, Katsina, Zaria and Kaduna among other places. In the South West, there were violent and communal conflict at Sagamu, Lagos, Ife-Modakeke crisis etc. in the South East; the Umuleri-Agleri conflicts. The communal and oil-induced conflict of the Niger-Delta especially in Warri and neighboring communities also increased in scope and intensity. Not even the transition from the military to democratic governance in 1999, with the accompanying assumptions that democracy provides alternatives to violent methods of conflict transformation, could slow down the prevalence of such conflict (Shedrack 2004).

In a general perspective of Nigeria experience in the aspect of conflict, one cannot ascertain the statics of inter-communal, ethno-religious, cultural-environmental conflicts in Nigeria. The Nigeria society can thus be described as a social system compounded by contested demands on access to scare resources in the political and economic field thus making the society vulnerable to the natural cleavages and man-made conflict (Otitie 2001). To corroborate Best (2004) assertion, the environment in Nigeria today has contributed in no small measure to the protraction of conflict. Going by the description of the European commission of environment, the 
environment comprises of the elements whose complex inter-relationship makes up the setting, the surroundings and condition of life of individual and of the society. Simply, the individual and society (environment) is a philosophical matter of egg and hen as to which comes first, whether it is discussed as an historical or psychological issue, man is the product of his environment (society). The Boko-Haram insurgency, the Fulani herdsman-farmers conflict, the cattle rustling, inter-communal conflict has been threaten the existence of the same as when the environment remain vulnerable to conflict and promotes conflictual interest, achieving a meaningful and sustainable development becomes problematic.

\section{Conceptualization}

\subsection{Conflict}

Conflict is a universal phenomenon. Peace researchers are not in agreement on the meaning of the concept of conflict. But the causes of conflict are numerous; its conception contains some identifiable variables that distinguish it from other concepts such as instability, violence and crisis. Taking into cognizance the experience of Nigeria in matters of conflict and insecurity, conflict occurs when two or more people engage in struggle over values and claims of status, owner and resources which the aims of the opponent are to neutralize, injure or eliminate their rivals (Coser 1956). This evolve when one party perceive or feels the other party is dominating in the socio-political and economic activities. It become protracted when different groups adopt different means, have different goals, and one sees each other as a hindrance. To this end, conflict thus can be considered indeed inevitable aspect of healthy functioning of all societies.

Oyeshola (2005: 101) proposes that there is conflict, 'When there is a sharp disagreement or clash, for instance, between divergent ideas, interests of people and nations'. He asserted further that 'conflicts are universal yet distinct in every culture. It is common to all persons yet experienced uniquely by every individual. It is a visible sign of human energy and often the result of competition for resources'. Conflict as explained above is considered to be a product of disagreement that may be rooted in the belief system and perceptions of threat to people's goals. Spangler and Burgess noted that "conflict involves deep rooted moral or value differences high-state distributional question, such as who dominates whom. Fundamental human psychological needs of identity, security and recognition are of issue as well" (Spangler and Burgess 2005)

The inevitable nature of conflict stems for the fact that for a society to exist, there must be interactions, which w2ill leads to mutual influence among individual elements of the society (Abrahamson 1990). More often than not, these social interactions and mutual influences often generate into disagreements among the interacting societal elements in the interaction would naturally protect its own interest above that of others this situation results in incompatible social behavior. A pragmatic example is the Nigeria experience of Farmers, community clashes against Fulani herdsmen. A critical look for explanation reveals that the crisis is nothing but dramatic changes in the economic sphere. Elbandawi and Hegre (2006) described it as 'economic shock' which has been fuelled with tension and greater concerns for access to resources.

\subsection{Peace}

Peace is the prime value of every society. In the twenty first century, peace is construed as a public good as it supports growth and development of human and material resources. Generally, peace is defined as freedom from disturbance, tranquility, absence of war, fear, conflict, anxiety, suffering, violence, and about peaceful coexistence. The Oxford English dictionary (Oxford Dictionary 2003) simply defined peace as a situation or period of time in which there is no war or violence in a country or area in a publication on peace and security. Steward, stated that peace is when people are able to resolve their conflicts without violence and can work together to improve the quality of their lives (Steward 2015). It can be concluded that peace is the required drive in the socio-economic development (education, trade and investment, health, welfarism and livelihood, justice, equality and fraternity (brotherhood), religious and ethnic tolerance, free, fair, and credible election, gender protection, human safety, and good governance.

Nigeria since the period of independence has been facing one form of violence or conflict which has been a threat to peace, human and material resources. Nigeria has had her share of socio-economic disruption; Boko Haram in the North East, kidnappings and oil pipeline vandalism in the East and South-south, the medical terrorism "EBOLA" in the West. Each and every one of these anti-social vices has disrupted economic activities in Nigeria. Of the aforementioned anti-social variables, religion induced crises seem to pose greater challenges in the study area. Apart from the Nigerian civil war of the late 1960s, the most catastrophic security challenge of Nigeria is the Boko Haram insurgency. For more than seven years, almost on a daily basis, it has been news of devastating bomb blasts, suicide bombings, assassinations, abductions, lootings, robberies, torture and rapes, as well as the wanton destructions of public and private property, including attacks on schools (Balami et al 2015). The absence of peace has hampered the development of agriculture, small scale business and manufacturing industries in North East of Nigeria especially Borno, generation of refugees and internally displaced persons in Adamawa, Zamfara, Benue, Taraba, and Yobe states as well leading to the high rate of economic loss, reduction 
in government revenues, reduction in the human development index of the state. Lack of peace and fragile peace has become the largest obstacle to the sustainable Development Goals (SDGs).

The peace question has to be seen in two aspects: peace should be conceptualized and perceived not only in the negative sense of minimizing or resolving conflict but also in the positive sense of creating material conditions which provide for the mass of the people a certain minimum condition of security, economic welfare, political efficacy and psychic well-being (Goodhand et al 1999). In general, peace researchers agreed that peace entails the absence of war (absence of direct conflict), peace as justice and development (absence of structural violence), peace as respect and tolerance between people, peace as Gaia (balance in and with the ecosphere, inner peace (spiritual peace) and peace as 'wholeness' and making whole (Shedrack 2005). In all and sundry, peace is a necessity for any meaningful development. There is no gainsaying that we need peace in our day to day errands, our markets, schools, churches, mosques footballs fields and wherever human beings exist all need peace as the becomes desert in a city when there is absence of peace

\subsection{Security}

Security is the prime responsibility of the state. The 1999 Constitution of the Federal Republic of Nigeria specifically states that "The security and welfare of the people shall be the primary purpose of government". Peace and security are inter-related concept when social welfarism of individual, community and states are considered. It becomes apparent to disclose that security is basically the condition of feeling safe or free from harm or danger or threat. It is the defense, protection and preservation of core-values of the people. According to the Oxford English dictionary (Oxford Dictionary 2003), it is the protection of a person, building, organization, or country against threat such as crime or attacks by foreign countries. It is, therefore, the degree of resistance to, or protection from harm. It applies to any vulnerable and valuable asset, such as a person, dwelling, community, nation or organization. The United Nations Development Programme, 'Human security connects different types of freedoms - freedom from want, freedom from fear and freedom to take action on one's own behalf (UNDP 2015). At a minimum, human security means freedom from violence and from the fear of violence. To this extent, security means freedom with due respect for the fundamental human right of citizens.

It is therefore apparent that national security is a desideratum, sine qua non for economic growth and development of any country (Oladeji and Folorunho 2007). In the intelligence community there is a consensus that security is not the absence of threats or security issues, but the existence of a robust mechanism to respond proactively to the challenges posed by these threats with expediency, expertise, and in real time. Thus there is a general consensus in the contemporary literature that security is vital for national cohesion, peace and sustainable development. Peace and security are both a prerequisite for, and critical aspects of development. High levels of insecurity will lead to lack of peace thereby making development impossible. It is, therefore, necessary for the reform of a country's security sector if development programs of a country are to progress (UNSD 2013).

\subsection{Development}

Scholars have identified strong links between security and development since the cold war ended. They argued that development cannot be achieved in any nation where there are conflicts, crisis and war. There is a consensus in the literature that security and development are two different and inseparable concepts that affect each other, and this has naturally triggered debates on security-development nexus (Chandler 2007). Likewise, peace and development are inextricably intertwined. Removal of conflict is only the minimalist condition for the attainment of peace. For a lasting and reliable peace to be attained, it is important to fashion economic systems which can generate sustained economic growth, guarantee for the mass of the population a certain minimum of material existence or basic needs. The African development experience for the last two decades has been a major disappointment, whatever the developmental options. The hopes of the early 1960's have not been fulfilled and disillusionment seems to have set in. This has led to a sobering reappraisal which has resulted in many debates is evident in her failure to deliver corresponding social goods and solve problems of unemployment, poverty, disease, hunger, illiteracy and ever increasing crimes and wars. The concept of development will be vied in various perspectives due to its ambiguity of the concept. 'Social development' refers to many of the noneconomic processes and outcomes of development, including but not limited to: reduced vulnerability; inclusion; wellbeing; accountability; people-centered approaches; and freedom from violence (World Bank 2008). Also, 'Human development' is a process of enlarging people's choices by building human capabilities to lead lives that they value (UNDP 2008). This involves the capability to live long in good health, to be educated, to access resources and social protection, and fair employment. As such, human development is also fundamentally concerned with human rights, including those to life, health and wellbeing. In another perspective, Economic development is the increase in the standard of living in a nation's population with sustained growth from a simple, low income economy to high-income economy. In all and sundry, the concept of development cut across the human and environment. 


\section{Conflict and Its Sources}

The sources of conflict are inherent in the relationship among individuals, groups of diverse ethnic, historical, religious and languages. Consequentially, the end products $f$ conflict is destruction with negative impact on the environment and humanity. Nigeria over the years has had its own fair share of the consequences of conflict. Although the Nigeria state is blessed and endowed with so much human and material resources, she has been and is still bedeviled by conflict and crisis both in her socio-economic and political sphere. The source of conflict in Nigeria ranges from inter-ethnic rivalries, religious, politics, and the environmental/resources sources of conflict. One consequence seems certain, there have been destruction of lives, properties and the displacement of millions of individual.

Nigeria is one of the largest and important state in Africa with the nomenclature 'Giant of Africa' or 'the Big-Brother Africa'. The Nigeria society has been characterized with widespread religious aggression and violence mostly among the two imported religion Christianity (Trans-Atlantic religion) and Islam (TransSaharan religion). The geographical configuration of Nigeria since the pre-colonial period, through the colonial period has made the issue of religion complicated with ethnic differences. Today religion has become the measurement of every activity in the state pushing it to the brink of collapse. The increasing institutionalization of religion into politics despite the secularism and the aggressive competition among the two religions has had a negative impact on Nigeria nation. Recently the confrontation among the leaders of both religions in matters of state has posed threat to the essence of state, governance and religion itself to humanity. Overtime, one can identify this notable religious violence.

In the Northern Nigeria where these issue of religion fundamentalism, extremism is becoming a threat has had so much on religious violence. In the 1970's, it was a decade of religious wrangling and public demonstration, the 1980's and 1990's were known for riots and outright political violence, countless tragedies and clashes (Falola 1998). The 1980' Maitatsine, 1962 intra-Islamic violence crisis in Kano and Kaduna state claiming hundreds of lives, 1984 religious crisis in Yola and Jimeta claiming over 600 life's, 1986 policestudent attack in national theater in Lagos, 1986 kwara state Muslim -Christian palm Sunday clash, 1987 religious crisis in Kaduna, Katsina, Zaria, kanfanchan, 1988 Ahamadu Bello university religious conflict (Bawa 2009). The 1991 religious in Bauchi, kano and Katsina over the riot of Yakubu Yahayaa, 1992 large scale violence in Zangon-kataf (religion and ethnic nationalism), Kaduna and Zaria, 1994 kano-sokoto religious crisis over the using of Quran as toilet paper, 1995 keno Muslim and Christian sporadic crisis, February 2005 reintroduction of Sharia in Zamfara, Niger and Kaduna states, October 2001 crisis over Osama Bin-Ladin 9/11 U.S bombing response in Kaduna and Gusau kano, 2013 Benue/ Nasarrawa clashes (Falola 1998).

The religious conflict in Nigeria has always taken the reflection of both religion has hidden under in the sphere of education, power and resource sharing, pilgrimage and missionaries works, area of Nigeria foreign policy. For instance the religious leaders clash over Nigeria joining the Organization of Islamic Country (OIC) and over the state funding of pilgrimages. The nature of religious conflict among the Christian in Nigeria is taking a dynamic status of socio-political undertone making it more complicated and threatening to Nigeria's survival, an exploited area for extremist, fundamentalist, political leader to perpetuate evil and cause disunity

Ethnicity tends to be used loosely to refer to commonality of language, religion, identity, national origin and even skin color. Ethnicity according to many sociologists and anthropologists, the core element in ethnicity has to do with "memories of a shared past", involving the collective memory of a people (Bates 1986). The challenges and opportunities of contemporary ethnic relations in Nigeria are shaped within the framework of social, political, economic and cultural institutions. Nigeria has experienced a bitter past when it comes to the issue of ethnicity. From the period of the European divide and rule system, the establishment of regional political parties, and the Akinsanya crisis of 1941 which sees the beginning of ethnic voting system in Nigeria. Ethnic rivalry has become a factor and source of conflict and backwardness in Nigeria, this has led to thousand of soul been annihilated, millions of properties and infrastructures have been destroyed in the name of dominance and marginalization

This is clearly evident in the 1999 Sagamu inter-ethnic crisis, 2002 Idi-Araba, Lagos ethno-religious crisis, 2002 Yelwa-Shendam crisis, 2011 Gwantom-Kaduna crisis, 2013 Benue-Taraba crisis, 2002-2005-2013 Wuse crisis, 2002, 2011, and 2013 Jos crisis (Bawa 2009). Ethnic groups in Nigeria consider ethnic loyalty first before national loyalty. They have transformed into ethnic militia who today uses ethnicity to cause a daunting challenge to the state. Violence, especially ethnic violence in contemporary Nigeria can be located in the internal contradictions and dialectics of the Nigerian Political economy. In' recent times such conflicts have been recorded in such places as Ilorin, Kafanchan, Kaduna, Funtua, Kano, Zaria, Ile-Ife, Zango-Kataf, while virtually all the oil producing communities of the Niger Delta have been the epic center of communal conflicts with the challenges of marginalization and social deprivation (Adejumobi 2003).

According to Adejumobi, in Nigeria, primordial identities of ethnic, communal and religious formations have taken the centre stage in social and political interactions (Adejumobi 2003). Ethnic socio-political organizations like the Afenifere, Ohaneze and Arewa Consultative Forum are perhaps the most palpable on the 
political turf. These groups have penetrating networks and profound influence in the Nation's political parties. The corollary of these groups especially at the youth level are the ethnic militias, such as Oodua People's Congress (OPC), Egbesu Boys of Africa (EBA), Movement for the Actualization of the Sovereign State of Biafra (MASSOB), Niger Delta Volunteer Force, ljaw youths, Arewa people's Congress (APC) and other religious militia groups in Northern Nigeria(Adejumobi 2003). These groups claim to represent specific ethnic or communal interest and adopt various tactics including violence in the conduct of their activities. This has in no small measure strangulated the developmental strategies of the Nigeria nation.

Conflict over natural resources is as old as human history. Nigeria in recent years has had another series of experience from the conflict over natural resources. Resources from nature are not evenly distributed over earth surface. Nigeria is blessed with mineral resources yet the different kind of climatic conditions, soil, topography, water bodies, natural vegetation, mineral wealth and other natural endowment are not evenly distributed over the earth surface. There is an increasing inter-dependence between man and resources (economy) and resources and politics in Nigeria. Conflict over control and ownership of geographical area rich in natural resources have been a source of conflict. Examples of such conflicts includes struggle over the ownership of oil wells and where oil pipes are located, Ogbogoro War (1998), the Obeakpu (Oyigbo) Conflict (1999), the Bille -Ke Conflict (2000), the Nembe War (2000) and the Olomoro- Oleh Conflict (2000) (Osaghae et al 2007). Other Instances from the South East Nigeria where oil is primarily dominated has witnessed series of conflict with the Federal government over budgetary allocation and revenue percentage due and oil companies to the destruction of land in the region during exploitation, manufacturing (pollution) and environmental degradation. This has given rise to ethnic militias in the region perpetrating crimes that generate into conflict such as kidnapping, oil bunkering and destruction of properties. Examples of such conflicts have been stated to include those of Umuechem vs. SDPC (1990), Ijaw vs. Chevron (December 2000), Elelenwo vs. Shell (2000), and Agalabiri \& Abadiorma vs. SPDC (July 2000) (Edith et al 2013). Land disputes among communities are another source of conflict that has assumed dangerous dimension. For instance, in Abakaliki of Ebonyi state in Nigeria, the communal war between Igbagu, the border town between Ebonyi and Ukelle people of Cross River State. According to Uka (2009), it claimed over 100 lives in 2009 ,

In the Northern Nigeria, the Tiv/Jukun crisis, the 2002 plateau crisis over th ownership of Wase town, the 2002 land dispute between the Eleme and Okirika people, the menace of Fulani-herdsmen encroaching farmlands, destroying crops and planted vegetation in every part of Nigeria has resulted into the death of thousands and several internally displaced citizen. As at 2003, Okaka town, an agrarian local community in Itesiwaju Local government area of Oyo state was at the receiving end of this menace. In 2010, there was a bloody clash between members of Umumilo Village and their counterpart in Abudum Village in Anambra state, Nigeria over alleged destruction of farm crops and economic trees worth a large sum of money, on a disputed portion of land, as well as the removal of an ancient boundary hedge demarcating the two communities. It took the intervention of armed police men to restore calmness to the villages (Odogwu 2011). The crisis had resulted in maiming, killing and displacement of thousands of people due to dispute over farming and land grazing (Ovuakpori 2011). Nigeria cassava Growers' Association estimated the loss of 20 million worth of cassava over 97 hectares area of land, 30,000 yam seedlings (Ezeonwuka and Igwe 2016). Cases of these encroachment includes March 5, 2015, in Riyan local government of plateau states , 10 people were killed with more than 100 houses burnt, in 6 March, Buwa Village in Ibi Local government area of Plateau, many people killed and houses burnt, The situation is not different in Nasarawa, Adamawa, Ogun, Delta and Cross River states where Fulani herdsmen persistently engaged farmers in feuds that often resulted in serious causalities on both sides (Sun Newspaper 2015: 18).

Nigeria has a long history of politically based violence since the collapse of the first republic on January 15 , 1966, and the incursion of the military into politics and governance that same date. The electoral politics in Nigeria right from 1960s till date have been characterized with violent conflicts, political thuggery, assassinations, and arson. Politicians in Nigerian do not accommodate dialogue, negotiation and consensus (Eme and Onyishi 2013). Political contests are characterized by desperation, and violent struggle for political power among politicians. Recurring political violence in Nigeria could be attributed to over-zealousness and desperation of political gladiators to win elections or remain in office at all cost. These misadventures have often been catastrophic leading to decimation of innocent lives, disruption of economic activities, and the destruction of properties among others. The integration of different ethnic group in Nigeria state is to say Nigeria is a conglomeration of different ethnic groups (Jaja and Jude 2013).

\section{Instrument of Resolutions and Nigeria Experience}

Conflict is naturally an inevitable part of human life. If conflict is managed and resolved effectively, there could be greatness, love and upward movement of socio-economic and political phases of live. Conflict resolutions are important for cooperation towards a sustainable development. Accordingly, the concept of conflict resolution can be thought to encompass the use of non-violent resistance measures by conflicted parties in an attempt to 
promote effective resolution (Robert and Garston 2009). Conflict resolution is a conceptual perspective that assumes individuals preferred method of dealing with conflict. Conflict resolution is seen as a variety of approaches aimed at terminating conflicts through understanding and constructive method of solving of problems. This will halt irrational violent behaviors and hostile attitudes from people either of ethnic, religious, political and socio-economical levels.

Added to the instrument above, on 20 May 2013, the Federal Government issued a formal Proclamation of the State of Emergency with the concurrence of the National Assembly. The preamble to this Proclamation acknowledges that

"Nigeria has been experiencing serious crises, internal tension and civil disturbances which presently constitute grave threats to peace, order, good governance, security and safety of life and property", and that "these crises and disturbances transcend religious, political, and ethnic divide with the perpetrators of the crises utilizing terrorist tactics, thereby occasioning serious breakdown of law and order (The National Human Right Commision 2013)

In the present, Nigerian situation is constantly threatened by security challenges in different parts of the country, it is therefore germane to put in place required conflict resolution mechanism to resolve these conflicts and avoid protraction. There is an enormous consideration before adopting any form of resolution approach. There are different forms of conflict resolution the Nigeria government has adopted. It is imperative to state that an understanding of the nature of conflict is important and necessary in order to determine the most appropriate and workable approaches and mechanisms of conflict resolution. This is because the understanding of the type of causes and actors will be a very useful tool for that purpose. However, the most common conflict resolution approaches or mechanisms in Nigeria include peace negotiations, mediation and arbitration, good governance/grass root community based activities.

Negotiation is one of the conflict resolution mechanisms. The term negotiation has been described by Ivorgba as a form of "collaboration . . . a situation where some people seek to satisfy their needs and interests while at the same time seeking to maintain relationships with others" (Ivorgba 2005). The glossary of the Berghof Foundation (2012) further described the process in a similar vein with Fisher and Ury (1991) in their 'Getting to Yes' as mode of communication between two parties that seeks to reach an agreement. According to the glossary, "negotiation" is a "face-to-face discussion for the purpose of reaching an agreement on a situation that is perceived as a problem or conflict" (Berghorf Foundation 2012). The process of negotiation involves procedures, communication, a direct process of dialogue and discussion taking place to settle conflictual interest among different parties. For example;

The Nigeria civil war between January 1967-1970 was characterized with ethnic chauvinism, political bickering, and resources control experienced different kind of negotiation before, during and after the war. Instances of this negotiation is the "Lagos Peace Conference", the national conference, which commenced in Lagos on September 11, Aburi Peace Conference, 1967 in Ghana by the Nigeria's Supreme Commander and Regional military governors, the Organization of African Unity (OAU) in November 1967 in May 23, 1968, Kampala Peace Talk (Aneke 2007). The Nigerian government overtime has proposed series of negotiation process with the Boko-Haram religious sect. As part of the negotiation methods employed by the federal government, the Special Adviser to the President on Media and Publicity Reuben Abati in a statement informed on a mode of strategy proposed. In his words,

"the ongoing talk is a back channel one in which those who know members

of the group are talking with them on behalf of the government"(Adeyemo 2012).

Recently, in addition to the conditions of ceasefire, the group had also asked for the release of its members imprisoned in exchange for the over 270 kidnapped schoolgirls (Alison 2014). The case of Niger-delta militant group can also not be left out. President Umaru Yar'Adua's administration in September 2008 considered a peaceful measure. In September 10, 2008, the administration constituted a Technical Committee to recommend ways to reduce violence in the region. This step bought a unilateral ceasefire from the militants. Consequently, the committee in December 2008 made several recommendations. These include: appointing a mediator to facilitate discussions between government and the militants; grant amnesty to some militant leaders; launch disarmament, demobilization, and rehabilitation campaign; and channeling $25 \%$ of the oil revenue to the Delta up from the current 13\%. However, dissatisfied by the recommendation, President Yar'Adua, in February 2009, constituted another committee to review the earlier recommendations on possible resolution of the ND unrest. The government, in the end, considered a "conditional amnesty" (Integrated Regional Information Network 2010). This is to suggest that the world is moving away from open confrontation (i.e war) to diplomacy, dialogue and negotiation

Arbitration/mediation has played a significant role in the settlement of ethnic/religious crisis in Nigeria. 
Arbitration involves is an agreement of the parties that the dispute between them be settled by a tribunal of their choice. Mediation on the other hand has been presented by the United Nations University for peace as the voluntary informal, non-binding process undertaken by external party that foster the settlement of differences and demands between directly invested parties (Miller 2003). In other words, arbitration and mediation involves the use and assistance of a neutral third party in conflict who hears the evidences from both parties and thereafter renders a decision which is expected to be binding $\mathrm{n}$ the parties. A perfect instance of arbitration in resolving conflict is seen in the agitation of the Niger Delta region in South-East Nigeria over resource control or derivation principle in the allocation of the Nigerian Federation Resources: The Niger Delta region believes that the $13 \%$ of oil revenue is too small; therefore, the people of the area agitate for a limit of $50 \%$ before the constitutional review committee. With their agitation and through arbitration process, there came an agreement that it would be pegged at 25\% (Chudi 2017).

Good governance and grassroots community based activities is another form of conflict resolution, and prevention depending on the response of the government. Good governance is running the affairs of the government in positive and progressive manners beneficial to the governed and delivers public services. In the presence of good governance, grassroots' community based activities will be described as a pro-active process that supports the process of de-escalating potential conflict or resolving an occurred conflict. In Nigeria, the Niger-delta region and several conflict ridden areas of the country has advocated for good governance and dividends of democracy. The ethnic militants are agitators in the political phases for good governance towards having a sustainable democracy. It is imperative to note that grassroots based activities is a potential source of deterring conflict in Nigeria because most resources conflict over land and territories; vegetations Nigeria is experiencing currently are as a result of neglect of government to the activities of this communal area. When the community solidarity is lost to violence then protracted conflicts remain the potential process of settling differences. Such instances are the Ife-Modakeke crisis in Osun state, the Chamba Jukun and Kuteb crisis in Taraba state, the Umuleri/Aguleri of Anambra states. All this conflict has become protracted and is potential threat to human lives and properties. In such manners, the importance of community virtues and good governance remain uncontestable.

As an agendum to the above, it is glaring that Nigerian government has employed some of the resolution process such as negotiation, arbitration, mediation, and collaboration. Some of this resolution instrument; such as good governance and grass-roots mobilization have not been effectively and efficiently engaged due to the state problem with leadership and sustainable democracy. However what have been the Nigeria experiences as far these resolutions are concerned? The Niger-delta crisis remains protracted, the boko haram insurgency continues with serial bombings, suicide bombers, kidnapping, political thuggery, killing and destruction of government and individuals properties. Ethnic violence assumed new phases as well as religious violence with burning of churches and mosques. Violence over resources in Nigeria has become a force to reckon with as community, individuals clashes remains protracted. Forty seven-years after the Nigeria civil war, the country is still bedeviled by the question of National Unity. Political violence and ethno-religious politics assumed the democratic process. Guaranteeing free, fair and credible election devoid of any conflict and violence during election remains obscure. Thus, the implication of such negotiation cultures, which lack the sense of protecting and ensuring a long term relationship with the other party, has been a source of problem compilation for Nigeria.

\section{Peace and Security as Panacea for Development}

Every nation of the world clamors for peace. It is well recognized all over the world that peace and security of life and property are the primary conditions for progress and development of any society (Arase 2007). The issue of peace remains one of the major focuses of national and international community. This is because there is a relationship between peace and sustainable development. Peace is actually a catalyst for national development. Development cannot take place in any nation without human security (Akamode 2004). The importance of peace and security to development is succinctly put by the United Nation Development Programme Administrator and Director, Thelma Awori in Adedeji, 1999, in the following lines

It is now widely accepted that violent conflict is a major hindrance to the development of African continent. It inflicts human suffering through death, destruction of livelihoods, constant displacements and insecurity. Violent conflicts distrupt the process of production creates conditions for pillage of the countries resources and divert their application from development purpose to servicing war. Violent conflict is thus responsible for perpetuating misery and underdevelopment in the continent (Victor 2005)

Peace and security is a panacea to development as conflict have the capacity to severely constrain development endeavors by destroying infrastructures, interrupting production process and diverting resources away from productive ventures. The panacea of peace and security to development would be examined in terms political development, economic development, social and human development etc. 
The importance of peace and security in economic development is that of necessity, according to Okowa (2005), development includes growth, income distribution, poverty alleviation and provision of basic needs of food, shelter, health and education for the masses. From a broader spectrum, Todaro posits that:

Development, in its essence must represent the entire gamut of change by which an entire social system, tuned to the diverse needs and desires of individuals and social groups within that system moves away from a condition of life widely perceived as unsatisfactory towards a situation or condition of life regarded as materially and spiritually "better". (Todaro 1981)

In other words, economic development embraces change that would improve the human elements, who in turn would improve their society - environment, social institutions, and per capita income of the citizen. This can only be feasible in a peaceful and secured atmosphere. In essence, the most important barometer for measuring development is peace and security. This concept of sustainable development in the $21^{\text {st }}$ century among the developing countries and with the sustainable development goal's of the United Nation strongly hinges on peace and security. The relevance of peace and security to economic development includes but not limited to encouragement of economic unity, attraction of foreign direct investment from foreign investors, establishment of industries and manufacturing industries, consequently job creation and available employment opportunities.

The political landscape of Nigeria, the formation of government through election and electioneering, distribution of power and decision making process. The Nigeria experience over the years has pose visible threat as the Nigeria political scene become dangerous on daily basis. The importance of peace and security to politics can be measured firstly in the aspect of election. With the parameters of peace and security Nigeria citizens can perform their civil rights of voting and contesting in electioneering. Nigeria election has always been characterized with killings, community clashes, electoral violence, political assassinations, and use of thugs to disturb voting process. Nigeria is a country where elections are "rigged" to occupy political positions, political appointments are based on God-fatherism, and employments are based on sentiments Nigeria is vulnerable to insecurity and conflicts emanating from the nature and character of politics in many states of the federation. Today the absence of peace and security in Nigeria politics has accounted largely for the deformed leadership, instability of government, corruption and bad government. Madu and Udezo (2010) maintained that Nigeria has democratic system of government but seems to be struggling with issues of accountability and good governance. The above scenario cannot lead to development and judicious utilization of human and material resources in the absence of peace and security in any nation. Peace and security are important parameters if the Nigeria needs political development such as the election of rational and merit leaders, management of its resources for growth, good governance that promotes justice, equality and an egalitarian society.

Peace and security encourages the improvement of infrastructural base of the nation such as roads, electricity, water, school, hospital among others to ensure a change in the standard of living of the citizenry. Peace and security encourages social development of the citizens and religious tolerance. Any nation with absence of unity as a result of violence and crime will not witness any appreciable national socio-infrastructural transformation.

As noted above, for development to take place in any society it requires sustainable peace. Scholars are in agreement that for there to be sustainable peace, society must evolve ways of addressing the root causes of conflicts by helping to foster participatory democracy, just and accountable governance, the rule of law, respect for human rights, and a balance and equitable distribution of resources, among a host of others(Chambers 2005)

\section{Recommendations}

From the foregoing discussion and the catalog of conflict and violence in Nigeria, the paper emphasized the importance of conflict resolution in abating conflict from degenerating into war. The paper thus makes the following recommendation.

- The introduction of peace and security studies into the Nigeria educational curriculum at this critical period of conflict and violence. If it properly designed, it would go a long way in appealing to our moral, psychology and perception about conflict. It would enlighten us and prevent cultural and ethnic conflict.

- The government should guaranteed and provide regular training for security personnel's in the state as well as equip them with modern technological equipment as to effectively combat threat and violence in the nooks and crannies of the state.

- A long-lasting solution or resolution to crisis should be adopted. This can be done through a detailed understanding of the cause, course, cost and crisis of the conflict. God governance and grassroots cooperation should be promoted as they are the potential roots of conflict. Information units of the country such as the Voice of Nigeria, National Orientation Agency should be empowered to sensitize and enlighten people about the causes, consequences of conflict and the need for peace and security. 
- History as a discipline should be made a compulsory at all level of education. This goes a long way in enlighten the new generations about the issues, conflict of the past and how they can avert such a conflict at the present. Man s product of his environment, man is necessarily a product of history, society and history are inter-twined. A citizen that doe not know where he/ she is coming from will eventually don't know where to go in terms of development.

\section{Conclusion}

The need for this study is driven by the serious conflict and insecurity challenges Nigeria is facing. Undoubtedly, peace and security cannot be guaranteed in Nigeria today. Nigeria has faced grave challenges that have threatened her corporate existence, both in the past and in the present. The paper has examined the concept of peace, security and conflict. The paper has also highlighted the various sources of conflict as well as the various instruments of resolutions. The paper concludes by examining the importance of peace and security to the growth and development of the state

\section{Bibliography}

Abrahamson. M. (1990). Sociological Theory: An Introduction to Concepts, Issues and Research (2 ${ }^{\text {nd }}$ Ed), New Jersey, Prentice-Hall

Adejumobi, (2003). Civic society, ethnic militia groups and the sovereign national conference. In T. Babawale (Ed.) Urban violence, ethnic militia and the challenges of democratic consolidation in Nigeria, 166. Lagos: Malthouse Press Ltd

Adeyemo, A. (2012, 13 November). Federal Government Begins Negotiation Talks with Boko Haram. Website title. Retrieved from: http:/www.bellanaija.com/tag/adeola-adeyemo/

Arase, S.E., Iwuofor P.O. (2007). Policing Nigeria in the 21st Century. Ibadan, Spectrum Books Limited

Akamode, O. (2004) Human Security and Development : Nigeria and Ethiopia. (Rapporteurs) Osita Agbu, Fred Agwu and James Osoata. Lagos: The Nigerian Institute of International Affairs

Allison, S. (2014). Should Nigerian Government Negotiate with Boko Haram? Website title. Retrieved from http://www.theguardian.com/world/2014/may/13/should-nigeria-negotiateboko- haram

Aneke, N. L. (2007). The Untold Story of the Nigeria-Biafra War: A Chronological Reconstruction of the Events and Circumstances of the Nigerian Civil War. New York, NY: Triumph Publishing

Balami, D.H., Ahmed F.F., \& Yusuf, A.B. (2016). The Imperative of Peace and Security For The Attainment of Inclusive Growth In Nigeria. European Journal of Research in Social Sciences Vol. 4 No. 2, 2016

Bates, R. H. (1986). "Modernization, Ethnic Competition, and Rationality of Politics in Contemporary Africa." in Marion, E.D and N.M. Stultz, (eds.) Governing in Black Afni'll. Revised Edition. New York: Africana Publishing House.

Bawa, M.M. (2009). Conflict and violence in Nigeria. In Salahu M.L and Bawa M.M. An Introductions to the History of Nigeria, People and Culture, Mirine, Al-Imam.P. 65-84

Berghof Foundation, (Ed.). (2012). Berghof Glossary on Conflict Transformation: 20 Notions for Theory and Practice. Berlin, Germany: Berghof Foundation Operations GmbH

Chudi, C. (2017). The Place Of Arbitration Practice In Resolving Ethnic And Religious Violence/Conflicts In Nigeria, European Centre for Research Training and Development UK (www.eajournals.org). Global Journal of Politics and Law Research Vol.5 No.5, pp.70-77

Chandler, D. (2007). The Security-Development Nexus and the Rise of „Anti-Foreign Policye. Journal of International Relations and Development Vol. 10, 362-386

Chambers, R. (2005). Ideas for Development. London, Institute for Development Studies

Coser, L. (1956). The Foundation of S0cial Conflicts, N.Y., Glencoe Hill Press DFID, (2001), The Causes of Conflict in Africa, Foreign and Commonwealth Office and Ministry f Defence, London

Edith, E.O., Comfort, R.O. (2013). Alternative Dispute Resolution Strategies for Sustainable Development in Africa: Insights From Nigeria. Journal of Management and Entrepreneurial Development Volume 3, Number 1, 2013

Elbandanwi I., Hegre H. (2006). Globalization, Economic Shocks and Armed Conflicts, Paper presented to the $2^{\text {nd }}$ ECPR Conference Marburg, Germany, September, 18-21

Eme, .O., Onyishi A. (2011). The Challenges of Insecurity in Nigeria: A Thematic Exposition. Interdisciplinary Journal of Contemporary Research in Business. Vol 3No 8.

Ezeonwuka, I. F., Igwe, A.U. (2016). Emerging challenges in Nigeria's national security in the twenty-first century: The Fulani herdsmen menace. Asian Journal of Multidisciplinary Studies, 4 (5), 207-209.

Fisher, R., Ury, W. (1991). Getting to Yes: Negotiating Agreement Without Giving In. New York, NY: Penguin Books

Goodhand, Jonathan, David H. (1999). 'From Wars to Complex Emergencies: Understanding Conflict and Peace building in the New World Disorder'. Third World Quarterly, 20:1 12-26. 
Integrated Regional Information Network. (2010). Nigeria: Timeline of Recent Unrest in Niger Delta Region. Abuja. Website title. Retrieved from www.irinnews.org/report/ 88002/Nigeria-timeline-of-recent-unrest-inNigeria-delta-region

Ivorgba, E. A. (2005). A Training Manual on Peace and Conflict Transformation. African Youths Development Forum. Retrieved from www.acydfoundation.cfsites.org/files conflict transformation.pdf Kantiok, J. B. (n.d.). Boko Haram,

Jaja, N., Jude O. (2013). Security and National Development in Nigeria: The Threat of Boko Haram. Journal of Humanities and Social Science Vol. 3 No. 4 (Special Issue - February 2013)

Madu, J.E., Udezo, B. S. (2010). The ethical dimensions of international incursions into Nigeria's political democratic agenda. In A.B.C, Chiegboka, T.C., Utoh E., Udechuchwu G.I., (Eds).The humanities \& globalization in the third millennium. Nimo: Rex Charles \& Patrick Ltd.

Miller C. (2003). A Glossary of Terms and Concepts in Peace and Conflict Studies, Geneva: University of Peace.

Odogwu, E. (2011). Court Wades Into Umuchu, Achina Boundary Crises. Retrieved on July 15, 2011 from Daily Champion Newspaper;

Okowa, W.J. (2005). “Oil, 'Babylonian Matheconomics' and Nigerian Development”. An Inaugural Lecture, University of Port Harcourt.

Osaghae, E. E., Ikelegbe, A., Olarinmoye, O. O., \& Okhomina, S. I. (2007). Youth Militias, Self Determination and Resource Control Struggles in the Niger- Delta Region of Nigeria. Darker Council for the Development of Social Science Research in Africa

Ovuakpori, E. (2011), Land Dispute: Reps Give Commission 2-week Ultimatum. Retrived on July 14, 2011 from the Vanguard Newspaper, http://www.nigeriaa2z.com/20 11/07/01/land-dispute-respnsive- commission-2weekultimatum/

Okpevra, U.B. (2009). Conflict and Crisis Management in Nigeria: The Ijaw-Itsekiri Experience, 1990-1999. Unpublished M.A Dissertation, University of Ibadan

Oladeji .S.I., Folorunso B. A. (2007), The Imperative of National Security and Stability for Development Process in Contemporary Nigeria. African Economic and Business review Vol. 5 No 2.

Otite, O., (2001) On Conflicts, Their Resolutions, Transformation and Management in Otite, Onigu, and Isaac Olawale Albert (Eds). Community Conflict in Nigeria: Management, Resolutions and Transformations, adan, Spectrum Books.

Roberts, A., Garston T. A. (Eds) (2009). Civil Resistance and Power Politics the Experiences of Non-Violent Action from Gandhi to the Present. Oxford: Oxford University Press.

Oyeshola, D.O.P. (2005). Conflict and Context of Conflict Resolution, Ile-Ife: Obafemi Awolowo University Press Ltd. P.101.

Shedrack, G.B. (2004), Protracted Communal Conflict and Conflict Management: The Bassa-Egbura Conflict in Toto Local Government Area, Nassarawa State, Nigeria. Ibadan; John Archers Press

Shedrack, G.B. (2005). Introduction to Peace and Conflict Studies in West Africa, Ibadan: Spectrum Books Limited

Steward, F. (2015). "Development and Security" Center for Research on inequality, Human Security and Ethnicity (CRISE).

Spangler, B. and Burgess, H. (2005). 'Settlement, Resolution, Management and Transformation: An Explanation of Terms'.In Beyond Intractability, edited by G. Burgess and

The Sun Newspaper, (2015). "Fulani Herdsmen and Food Security" by Bilkis Bakare Friday Oct 9th, p18.

Todaro, M.P. (1981). Economic Development in the Third World, (8th Ed.). London: Longman Publishers The National Human Rights Commission (2013). The Baga Incident and The Situation in North- East Nigeria An Interim Assessment and Report. Available @www.nigeriaright.gov.ng= Retrieved 22/06/2018

The Oxford English dictionary, (2003). Peace. Oxford University Press

Toyin, F. (1998). Violence in Nigeria; the Crisis of Religious Politics and Secular Ideologies. University of Rochester Press

Uka, F. (2009). Ebonyi, Cross River Boundary Crisis Claims 100 Lives. Retrieved on July 8, 2011 from Daily Independent Newspaper, http://allafrica.com/stories/200 909070933.html

United Nations Development Programme (UNDP), (2015) Insecurity and Violence in the Post-2015 Development Agenda Paper prepared for the Small Arms Survey, For UNDP at the occasion of the Global Dialogue on the Rule of Law and post-2015 Development Agenda, New York.

United Nations Sustainable Development Solutions Network (SDSN), (2013)). An Action Agenda for Sustainable Development, www.unsdsn.org Retrieved June 2018.

United Nation Development Programme, Human development reports: http://hdr.undp.org/en/humandevlopment Victor Adetula. (2005). Development, conflict and peace building in Africa in Shedrack . G.B. Introduction to Peace and Conflict Studies in West Africa, Ibadan: Spectrum Books Limited

World Bank, Social development overview: http://www.worldbank.org/en/topic/socialdevelopment/overview\#1). 